\title{
C
}

\section{Resorting to the Use of Force in Nuclear Operations}

This section is concerned with the law that regulates the resort to the use of force, often referred to as jus ad bellum. Jus ad bellum, largely based on the United Nations Charter, sets forth the general prohibition on the employment of force by States in the conduct of their international relations and contains the two recognised exceptions to that prohibition. Jus ad bellum is to be distinguished from jus in bello (i.e. the body of law which regulates the conduct of hostilities once an armed conflict is under way). The two bodies of law are distinct but are not entirely unrelated. Importantly, however, the principle of the equal application of jus in bello to the parties to an armed conflict means that, irrespective of which party may have perpetrated a breach of jus ad bellum and thus caused the armed conflict, the rights and obligations of jus in bello (as set forth in Sections $\mathrm{E}$ and $\mathrm{G}$ ) and the law of neutrality (as explained in Section F) apply to both parties to the conflict equally. ${ }^{1}$

All States are party to the United Nations Charter and therefore its provisions bind all States as a matter of treaty law. The question of whether the contents of the UN Charter have customary law status is not entirely moot, as such status may, for example, have implications for the applicability to armed groups of some aspects of the law relating to armed attack. It is the opinion of the present authors that the provisions of the UN Charter that are referred to in this section do indeed have customary law status, with the consequence that actions of armed groups are capable of constituting armed attacks if the threshold applicable to armed attack is met.

The International Court of Justice (ICJ) has opined that Articles 2(4) and 51 of the UN Charter apply to 'any use of force, regardless of the weapons employed'. ${ }^{2}$ It expressed this view when considering the legality of the threat or use of nuclear weapons. It is therefore considered to be uncontroversial that

1 Preamble to API, para. 5; UK Manual, paras. 3.12, 3.12.1; Canadian Manual, para. 204.

2 ICJ Nuclear Opinion, para. 39. 
the Rules set forth in this Section apply to the threat or use of nuclear weapons. For a discussion of the ICJ's Advisory Opinion, see Section J.

\section{Prohibition of the Threat or Use of Nuclear Force}

\section{Rule 8}

All States must refrain in their international relations from the threat or use of nuclear force against the territorial integrity or political independence of any State, or in any other manner inconsistent with the purposes of the United Nations.

1 This Rule is based upon, and adopts the language of, Article 2(4) of the UN Charter. It is a rule of customary international law. ${ }^{3}$ Acts or threats of nuclear force that 'are not directed against either the territorial integrity or political independence of a State may nevertheless violate the prohibition if they are inconsistent with the Purposes of the United Nations'. ${ }^{4}$ The meanings of 'use of force' and 'threat of force' are addressed respectively in Rules 9 and 10.

2 The territorial integrity ${ }^{5}$ of a State can sensibly be understood to refer to the practical ability of the attacked State, with its government and administration, both national and local, to continue to operate throughout its territory. A nuclear attack that has the effect of depriving the government of that State of the ability to exercise its sovereign rights and responsibilities throughout the territory of the State, for example, by denying safe access to a portion of the territory, will have been a use of force against the territorial integrity of the State.

3 Political independence refers to the right of the State to employ its own political processes and to make its own political decisions without external interference. It is the use of nuclear force, or a threat to use nuclear force, with the purpose thereby of forcing or influencing political processes or decisionmaking within the victim State that this part of the Rule prohibits.

4 The purposes of the United Nations are set forth in Article 1 of the UN Charter. They are:

1 To maintain international peace and security, and to that end: to take effective collective measures for the prevention and removal of threats to the peace, and for the suppression of acts of aggression or other breaches

ICJ Nicaragua Judgment, paras. 188-90.

4 Tallinn Manual 1.0, Commentary accompanying Rule 10, para. 2.

'Integrity', so far as relevant in the present context, is defined as 'the state of being whole; the condition of being unified or sound in construction'; see Concise Oxford English Dictionary, 11th ed. (Oxford University Press, 2006) 738. 
of the peace, and to bring about by peaceful means, and in conformity with the principles of justice and international law, adjustment or settlement of international disputes or situations which might lead to a breach of the peace;

2 To develop friendly relations among nations based on respect for the principle of equal rights and self-determination of peoples, and to take other appropriate measures to strengthen universal peace;

3 To achieve international co-operation in solving international problems of an economic, social, cultural, or humanitarian character, and in promoting and encouraging respect for human rights and for fundamental freedoms for all without distinction as to race, sex, language, or religion; and

4 To be a centre for harmonizing the actions of nations in the attainment of these common ends.

A threat or use of force that is in any way inconsistent with these purposes breaches Article 2(4) of the UN Charter. It follows from the foregoing that the use of any force, including by means of nuclear weapons, is in violation of Article 2(4) and of the corresponding prohibition under customary law. The illegality of such use or threat thereof may, of course, be precluded by either self-defence or UNSC authorisation.

5 The Rule is concerned with the actions of States: it is States that are the object of the prohibition. Moreover, it is the armed forces of a State that will usually - perhaps almost invariably - be responsible for maintaining and operating nuclear weapons. It should be borne in mind, however, that, for these purposes, activities of a State's intelligence agency would be regarded as the actions of the State. Similarly, in the most unlikely event that a private contractor is responsible for maintaining and operating a State's nuclear weapon facilities, the actions of that private contractor may well be attributable to the State and may, thus, be regarded as the actions of the State. Attribution and state responsibility are addressed in Rule 6 and in the accompanying Commentary. Importantly, Article 2(4) of the UN Charter and its associated customary prohibition of the use of force do not apply to non-State actors unless, as mentioned earlier in this paragraph, their acts are attributable to a State. If a threat or use of nuclear force is undertaken by terrorists, by an organised armed group or even by individuals and is attributable to a State, it is the State that will have breached Article 2(4), not the group or the individuals.

6 If a threat or act falls below a threat or use of force for the purposes of this Rule, it may nevertheless constitute an unlawful intervention (on which, see the Commentary accompanying Rule 9). 


\title{
Meaning of Use of Force
}

\author{
Rule 9 \\ A nuclear operation amounts to a use of force when its scale \\ and effects reach the threshold of a use of force.
}

1 It will be recalled that, for the purposes of the present book, a 'nuclear operation' includes all activities involving the use or threatened use of nuclear weapons, nuclear deterrent activities and all actions whose purpose is to target nuclear weapons and nuclear equipment as such, including their command, control and communications systems. As the present Rule makes clear, not all nuclear operations qualify as a use of force, but only those that fulfil the elements discussed in the following paragraphs.

2 The UN Charter does not specify which acts do or do not constitute a use of force. The ordinary meaning of the term force is 'physical coercion'. Accordingly, the use of means that are designed to cause, or in fact result in, damage, destruction, injury or death qualifies as a use of force. Such a broad interpretation would not, however, be based on a sufficiently broad consensus among States. In the light of the Charter's preamble - 'to save succeeding generations from the scourge of war' - it is safe to maintain that the use of methods and means of warfare will always have to be considered by reference to Article 2(4).

3 In determining which nuclear operations amount to a use of force, it is useful to note the statement by the ICJ in the Nicaragua case that 'scale and effects' must be considered when determining whether particular acts amount to an armed attack. ${ }^{6}$ This would seem to be a helpful yardstick also for drawing the distinction between events that constitute a use of force and those that are something less. In other words, the scale and effects of an event can be used as the basis for distinguishing between uses of force and acts that should be regarded as de minimis and thus as not constituting a use of force. According to this approach, it is the nature and the degree of the consequences of a nuclear event, or of the expected consequences of a threatened nuclear event, that will determine whether it can properly be regarded as a use or threat of force. Moreover, it is widely accepted that mere economic or political pressure is not sufficient to constitute a use or threat of force. ${ }^{7}$

6 ICJ Nicaragua Judgment, para. 195; Tallinn Manual 1.0, Commentary accompanying Rule 11, para. 1.

7 This is so, even if the economic or political pressure prejudices the territorial independence or political integrity of the victim State. This is because political or economic pressure is not synonymous with the use or threat of force; see Tallinn Manual 1.0, Commentary accompanying Rule 11, para. 2. 
$4 \mathrm{~A}$ use or threat of nuclear force will usually be undertaken by the armed forces of a State. However, a nuclear-capable State might become involved in a non-international armed conflict by, for example, arming and training an organised armed group that is undertaking hostilities against the government of another State. The acts of arming and training the organised armed group might qualify as a use of force by the assisting State, particularly if they are accompanied by other significant assistance. ${ }^{8}$ If, troublingly, nuclear material were to get into the hands of a non-State actor and if that non-State actor threatens to use it or actually uses it, that would not constitute a breach of Article 2(4), because that Article is limited to threats or acts by States. If, for example, an organised armed group were to lodge nuclear material or a nuclear weapon in a concealed location within a State and with that State's permission, the mere act by the State of giving that permission would not, without more, be generally regarded as sufficient for a subsequent threat or use of the nuclear material by the group to be regarded as a threat or use of force by the State. In the same example, if, however, the provision of such 'safe keeping' facilities were to be accompanied by other significant assistance from the State - such as the provision of a launch location and/or the supply of equipment required to launch such a weapon - the subsequent threat or use by the group would likely be regarded as a threat or use of force by that assisting State. ${ }^{9}$

5 As noted in the Commentary accompanying Rule 11 below, a nuclear event must rise to the level of an armed attack for the victim State to have the right to use force in self-defence. It is important to understand the relationship between actions that constitute a use of force and those that amount to an armed attack. The ICJ has described armed attacks as the most grave forms of the use of force. ${ }^{10}$ So, any armed attack that is conducted by or attributable to a State will also constitute a use of force, but not all uses of force will amount to an armed attack. Accordingly, the authors reject the view, expressed by the United States, that any unlawful use of force is capable of being regarded as an armed attack triggering the right of the victim State to use force in self-defence. In the authors' view, only the most grave forms of use of force so qualify. ${ }^{11}$

6 It is generally agreed that " $[a]$ cts that injure or kill persons or damage or destroy objects are unambiguously uses of force, ${ }^{12}$ and one, if not all, of those

8 ICJ Nicaragua Judgment, para. 228.

9 Consider Tallinn Manual 2.0, Commentary accompanying Rule 69, para. 5.

10 ICJ Nicaragua Judgment, para. 191.

1 Consider US DoD Law of War Manual, para. 1.11.5.2; A. D. Sofaer, 'International Law and the Use of Force', 82 (1988) Proceedings of the ASIL Annual Meeting 420, 422.

12 Tallinn Manual 2.o, Commentary accompanying Rule 69, para. 8. 
four occurrences - death, injury, damage or destruction - is the likely and perhaps inevitable consequence of a military operation involving the use of a nuclear weapon. Less straightforward is the situation in which either none of the four occurrences is caused or in which the casualties or damage are at the lower end of the spectrum. Consider, for example, a situation in which a State has taken action to try to render another State's nuclear command structure inoperable - say, by undertaking directed energy attacks against the computer equipment on which the nuclear command system relies. In the opinion of the present authors, there are two interlinked issues that arise when determining whether an event is a use of force contrary to Article 2(4). The first issue is whether the relevant event fulfils the legal criteria for establishing a use of force. The second issue is whether the victim State chooses in fact to characterise the event as a use of force - a decision that in turn will be influenced, but not necessarily determined, by what the victim State deduces would be the likely interpretation of the community of States.

7 Taking those issues together, it has been suggested that victim States will consider a number of factors when deciding whether to characterise an event as a use of force. The author of the original list ${ }^{13}$ was identifying the factors States would have in mind when deciding whether to regard a specific cyber event as a use of force. He was at pains to make it clear that these factors do not represent legally prescribed criteria and the present authors think it instructive to consider how those factors can usefully be applied to nuclear operations. The present authors would therefore suggest that the 'Schmitt criteria' might be interpreted as follows:

Severity: Events that cause inconvenience, irritation or even anger, and little more, will not amount to a use of force. Events that cause physical harm will usually be capable of being a use of force, unless the harm is relatively minor. If important national systems are affected, but only to a minor degree, the importance of the systems will not cause the event to be a use of force. Accordingly, 'the scope, duration, and intensity of the consequences will have great bearing on the appraisal of their severity'. ${ }^{4}$ So, to continue with the example of the attack on the nuclear weapon computerised control system, a military operation that has only a temporary disabling effect on such a system lasting a few seconds or a couple of minutes might not

13 M. N. Schmitt, 'Computer Network Attack and the Use of Force in International Law: Thoughts on a Normative Framework', 37 (1999) Columbia Journal of Transnational Law 885, 914; Tallinn Manual 2.o, Commentary accompanying Rule 69, para. 9.

14 Tallinn Manual 2.0, Commentary accompanying Rule 69, para. 9(a). 
be regarded as a use of force, whereas one that takes the control system offline for a longer period is likely to be regarded as a use of force.

Immediacy: If a military operation has immediate adverse consequences, the victim State is poorly placed to prevent the ensuing harm and will thus be more likely to interpret the event as a use of force.

Directness: The more direct the causal link between the event and the harmful consequences, the more likely a State is to regard the event as a use of force. It is hard to think of a more direct link than that between the detonation of a nuclear device and the harm caused by the blast, the fragmentation and the contamination caused by the nuclear particles.

Invasiveness: This factor is concerned with the degree to which a particular operation invades a State's systems. The arrangements that a State develops for the command, control and communications associated with its nuclear forces are likely to comprise closed systems, unconnected to the Internet and with security measures, perhaps of an elaborate nature, designed to ensure that unwanted intrusion is prevented. So, for example, a military operation that intrudes into the nuclear weapon command system and that breaks a secure communications link, such as that between a superior commander and the commanders of nuclear-armed submarines, will certainly satisfy the invasiveness criterion. Equally, if a cyber or sabotage operation is targeting the private systems of a single State, the invasiveness criterion is likely to be satisfied. Note, however, that while espionage is highly invasive, it will not, without more, amount to a use of force and espionage does not breach the law of armed conflict.

Identifiable effects: If the effects of the nuclear operation can be objectively identified and even measured in some way, the operation itself is more likely to be seen as a use of force. Again, a nuclear explosion satisfies this criterion, in that the casualties can be counted, the area of land adversely affected can be measured and the structures that are damaged or destroyed can be listed. Equally, the impact of an operation to disable an enemy military command and communications system can be measured in terms of the duration of the disruption, the nature of the systems that are disabled, the functions that cannot be performed and so on.

Military character: The military nature of an activity will increase the likelihood of it being regarded by a victim State as a use of force. The use of a nuclear weapon, or a threat to use such a weapon, will be an 
event that is inevitably seen as military in nature, so this criterion will ordinarily be satisfied by either of those acts. Actions taken adversely to affect another State's nuclear command, control and/or communications may take a form that would not necessarily have military appearance. Thus, hacking operations undertaken from a nonmilitary location, using civilian computing equipment, operated by civilians and undertaken through intermediary servers may not have the outward appearance of military activity. However, States are likely to view the target of such an operation as, per se, giving the operation military character and as thereby satisfying this criterion.

State involvement: There are two aspects to state involvement. First, the Article 2(4) prohibition specifically addresses States, so if a State is not in fact involved and is not seen to be involved, directly or indirectly, in the activity, then the activity cannot amount to a breach of Article 2(4). Second, the more visible the connection is between a State and the forceful activity being undertaken, or threatened, against another State, the more likely it is that third States will regard the activity as being a use of force.

Presumptive lawfulness: The provisions of the law of armed conflict generally prohibit acts or limit the circumstances in which they may lawfully be performed. It has therefore been suggested that acts which are not prohibited, either generally or in the relevant circumstances, are permitted. ${ }^{15}$ This then leads to the somewhat circular argument that acts which are presumptively legal are less likely to be considered by States to be a use of force. If, during a period of peace, a State fires a nuclear weapon at another State, there is no presumptive lawfulness involved. The act is a manifestly unlawful use of force and will be seen as such by the global community at large. However, if a State is covertly gathering information about another State's $\mathrm{NC}_{3}$ systems, such activity is not prohibited by international law. During such an espionage operation, the secretive insertion of a kill switch or some other device to damage the intruded systems may well not be publicly visible, may therefore not cause States in general to appreciate the full nature of the action being taken and may accordingly be that much more difficult to characterise as a use of force.

8 Other factors will influence a State's publicly stated position on whether a use or threat of force has taken place. These will likely include: the 
political and diplomatic situation pertaining at the time; the strategic situation in which the victim State finds itself; any relevant rhetoric from the political and/or military leadership of the State believed to be responsible for the use or threat of force; any relevant events during the period preceding the act being assessed; and the kind of target against which force has been used. It is important to emphasise that the factors listed here and in the previous paragraph do not have legal force, that not all of them need to be present for an event to be classifiable as a use of force and that categorisation as a use of force is for the victim State to decide, basing its decision on a reasonable but necessarily subjective appreciation of what has happened.

9 It should be noted that not all uses of force are unlawful. Thus, if necessary and proportionate force is used in lawful self-defence (on which, see Rules 11, 12,13 and 14) or if force is lawfully used pursuant to an authorisation by the United Nations Security Council (on which, see Rule 17 below), there will be no breach of the present Rule.

10 The implications of the distinction between a 'use of force' and an 'armed attack' must be fully understood. The former constitutes a breach by a State of an international law rule - namely, the prohibition in Article 2(4) of the UN Charter and in customary law. The perpetrating State has therefore committed an internationally wrongful act against the victim State, giving the victim State the right to take non-forceful countermeasures (see Rule 7 above). 'Armed attack', by contrast, is the state of affairs that must occur before a victim State has the legal right to use force by way of self-defence. A use of force contrary to Article 2(4) that does not also amount to an armed attack gives the victim State no right to use force in selfdefence. Only if an armed attack occurs does the victim State have the legal right to act forcefully in self-defence (on armed attack and self-defence, see Rules 11, 12, 13, 14 and 15).

\section{Meaning of Threat of Force}

\section{Rule 10}

A nuclear operation amounts to an unlawful threat to use force when the threatened action, were it to be carried out, would be an unlawful use of force.

1 The prohibition of the threat or use of force is set forth in Rule 8 .

2 It must be recalled that, for the purposes of this book, the term 'nuclear operation' includes all activities involving the use, or threatened use, of nuclear weapons, nuclear deterrent activities and all actions whose purpose 
is to target nuclear weapons and nuclear equipment as such, including their command, control and communications systems. The notion of unlawful use of force is described in Rule 9 and the accompanying Commentary. If the force being threatened would be lawful - for example, because it would constitute necessary and proportionate force lawfully used in self-defence, or because it is authorised by the United Nations Security Council - the threat to use it will not be unlawful. In other words, for the threat to be unlawful, the force concerned must also be unlawful. The focus of the present Rule is on Article 2(4)'s prohibition of threats to use force, and most particularly on what constitutes a threat for these purposes.

3 The making of a threat involves the expression of an intention. Accordingly, the Tallinn Manual explains that the "essence of a threat is that it is explicitly or impliedly communicative in nature'. ${ }^{16}$ If a State merely acquires the capability to use nuclear force, this does not constitute an unlawful threat as no express or implied threat is being communicated. However, if, for example, the political leadership of the State were to publicly disclose that it has obtained the means to use a nuclear weapon and intends to use it against a named State unless that State takes specified action or desists from stated activities, that would constitute a threat to use unlawful force.

4 A more complex issue concerns the lawfulness of a nuclear deterrent policy. It makes sense at this point to note some of the remarks about deterrence made during the ICJ's deliberations on the lawfulness of the threat or use of nuclear weapons in the mid-199os, although these are also discussed in Section J below. The ICJ observed:

Some States put forward the argument that possession of nuclear weapons is itself an unlawful threat to use force. Possession of nuclear weapons may indeed justify an inference of preparedness to use them. In order to be effective, the policy of deterrence, by which those States possessing or under the umbrella of nuclear weapons seek to discourage military aggression by demonstrating that it will serve no purpose, necessitates that the intention to use nuclear weapons be credible. Whether this is a 'threat' contrary to Article 2, paragraph 4, depends on whether the particular use of force envisaged would be directed against the territorial integrity or political independence of a State, or against the Purposes of the United Nations or whether, in the event that it were intended as a means of defence, it would necessarily violate the principles of necessity and proportionality. In any of these circumstances the use of force, and the threat to use it, would be unlawful under the law of the Charter. ${ }^{17}$

16 Tallinn Manual 2.0, Commentary accompanying Rule 70, para. 4.

17 ICJ Nuclear Opinion, para. $4^{8 .}$ 
5 The Court declined to pronounce on the policy of deterrence but noted the fact that a number of States adhered to the practice during much of the Cold War and continued to do so. ${ }^{18}$ As can be seen, the Court did not explicitly state whether the act of maintaining a policy of deterrence actually constitutes the communication, directly or indirectly, of a threat. One interpretation of the words used in paragraph 48 of the Advisory Opinion might suggest that members of the Court thought that a deterrence policy does indeed entail such an effective communication. An alternative interpretation would suggest that this was a subject on which the Court was deliberately declining to express a firm view.

6 In the view of the authors, a threat for present purposes necessarily must be directed towards another State or States. There must be a prospective victim of what would be an unlawful use of force. The mere taking of precautions in order to seek to promote a State's own security does not constitute the communication of a threat. Likewise, the development and maintenance of a nuclear capability as a deterrent against States in general does not amount to a threat for these purposes, because no threat is being communicated to any State in particular. It is only if a threat to use unlawful force is explicitly being communicated to a target State or States, or if the acts of the threatening State clearly show and thus communicate that it is intending to use unlawful force against a specific victim State or States, that an unlawful threat has been issued. It must, however, be made clear that, for a number of States, the mere possession of nuclear weapons by other States constitutes an implicit threat to use them in unspecified circumstances on unknown and unknowable occasions in the future. The position of such States is that the possession of nuclear weapons and the maintenance of a nuclear deterrent is therefore a breach of Article 2(4) of the UN Charter and, thus, is unlawful. The authors do not agree with that approach. In their view, an unlawful threat under Article 2(4) exists only where there is a communication by or on behalf of one State directed at another State or States that directly or indirectly threatens that State or those States with the use of unlawful force; a general policy of deterrence does not fulfil those criteria. Moreover, the approach taken by such States is not shared by those States that either maintain a nuclear deterrence policy or that have put themselves under the umbrella of nuclear weapon States. Accordingly, there is a lack of general consensus both on the interpretation of Article 2(4) and with regard to customary international law.

18 ICJ Nuclear Opinion, para. 67. In para. 73 the Court described the practice of deterrence as 'still strong', and in para. 96 it commented that an appreciable section of the international community had been adhering to the policy for many years. 
Specifically, in the opinion of the present authors, it cannot be said that there is a general practice of States accepted as law that equates deterrence with the communication of a threat.

7 A threat in breach of Rule 8 does not have to be accompanied by a coercive demand. Accordingly, if a State simply threatens to launch a nuclear weapon against another State without demanding specified action by the victim State as the price for not undertaking the attack, that would nevertheless be an unlawful threat contrary to Article 2(4). Likewise, a threat by one State to destroy a military facility where it believes another State holds part or all of its nuclear arsenal does not have to be accompanied by specific demands directed at the victim State for that threat also to constitute a breach of Article 2(4). A more difficult situation arises if the political leadership of a State threatens to undertake a nuclear attack when it is clear that it has no capability to do so. Expert opinion is divided on whether that would amount to a breach of the Rule. Much will inevitably depend on the precise words used and on the circumstances in which they are uttered.

\section{Armed Attack and Self-Defence}

\section{Rule 11 \\ A State has an inherent right of individual or collective self-defence if an armed attack occurs against it.}

1 While the wording of the Rule follows closely that of Article 51 of the UN Charter, the right of a State to use force in self-defence is also a customary law right. The language of Article 51, and of the Rule, shows why it is important to clarify the characteristics of armed attacks.

2 To be an armed attack, the relevant military operation must cross an international border. So, the firing of a missile from a submarine located in international waters against a land-based target in a State and the flying of a combat aircraft from one State into the airspace of another State in order to drop a nuclear bomb in that State are both examples of a cross-border operation that will satisfy this criterion. Equally, if State A sends a special forces team from its own territory into State B in order to target and destroy an industrial installation used for the manufacture of ingredients for a nuclear device, this will also involve a sufficient cross-border element for present purposes. If the cross-border aspect is absent - in other words if, say, the attack on the industrial installation is planned and executed entirely from within the target State by an organised armed group at a time when no pre-existing armed 
conflict is in progress - such an event cannot be classified as an armed attack. If the number and gravity of previous violent events are sufficient to show that a non-international armed conflict is taking place, the State's response will be governed by the law of non-international armed conflict. If the threshold of a non-international armed conflict has not been reached, human rights law and the domestic criminal and police law of the relevant State will determine the lawful responses of its law enforcement agencies.

3 The ICJ noted in its Nuclear Weapons Advisory Opinion that Article 51 does not specify the means whereby an attack must be undertaken in order for it to constitute an armed attack. The provision applies 'to any use of force, regardless of the weapons employed'. ${ }^{19}$ This does not, however, mean that a weapon must be employed. It is the effects generated by the operation that are critically important here. If these are comparable to the effects normally associated with an armed attack, the mere fact that they were generated in a novel manner does not per se preclude the resulting operation from being treated as an armed attack. Consider, for example, a cyber operation that intrudes into the computer systems that control stored nuclear warheads. The intruder intentionally alters the storage arrangements so as to facilitate a large release of nuclear material. As a result, a number of staff members at the facility are killed, several warheads are extensively damaged and major environmental contamination is caused. The mere fact that a non-kinetic method is used to cause the casualties, the damage to the warheads and the environmental contamination does not prevent the cyber activity from amounting to an armed attack.

4 The authors take the view that not every use of force contrary to Article 2(4) of the UN Charter rises to the level of an armed attack. ${ }^{20}$ It is the scale and effects of the operation that will mark the distinction here, ${ }^{21}$ and these will be greater for armed attacks than for uses of force not amounting to an armed attack. The distinction is of utmost importance, as a victim State is permitted to use force in self-defence only in connection with an armed attack. When discussing 'scale and effects', the ICJ Nicaragua Judgment distinguished 'the most grave forms of the use of force (those constituting an armed attack) from other less grave forms'. ${ }^{22}$ This causes one to wonder what grave scale and effects might look like. The ICJ did not give guidance on that issue, although expert opinion suggests that serious injury to, or death of, a number of persons

19 ICJ Nuclear Opinion, para. 39.

$20 \quad$ ICJ Nicaragua Judgment, para. 191.

21 ICJ Nicaragua Judgment, para. 195.

22 ICJ Nicaragua Judgment, para. 191. 
or significant damage to, or destruction of, property would satisfy the requirement. ${ }^{23}$

5 While the threshold for armed attack is not defined in measurable terms, any use of a currently available nuclear weapon is highly likely to have sufficiently serious effects to constitute an armed attack. The possibility cannot, however, be entirely excluded that at some future time very limitedyield nuclear devices will be developed, the damaging and injurious effects of which might be significantly reduced. Moreover, operations against nuclear weapon capabilities may have effects at or around the threshold. It should therefore be borne in mind that if, for example, a State undertakes a series of attacks which, individually, would not meet the armed attack threshold, they might be considered cumulatively as having the required scale and effects. ${ }^{24}$ For this approach to apply, however, the incidents in the series would need to be sufficiently related. Suppose, for example, that a State has on three recent occasions used proxy individuals in a neighbouring State to attack a railway line, causing a derailment with few casualties; set fire to a warehouse, causing the loss of some construction materials; and initiate a power surge, causing damage to numerous domestic appliances and some commercial equipment. None of these events would individually, or possibly cumulatively, constitute an armed attack. If, however, in a fourth incident, the same State disables part of the nuclear communications network, causing damage that requires the replacement of numerous components and the re-validation of the system, the victim State might be able to show that the cumulative scale and effects of the series of related incidents meet the armed attack threshold. ${ }^{25}$

6 A challenging question is which non-injurious, non-damaging cyber operations against nuclear command, control and communications systems can constitute an armed attack. It is evident from the discussion in Tallinn Manual 2.o that expert opinion is likely to be divided. The present authors take the view that the nuclear command, control and communications systems of a State will be regarded as part of that State's critical national infrastructure. They further consider that any operation against such infrastructure that

23 Tallinn Manual 2.0, Commentary accompanying Rule 71, para. 8. Note the later suggestion by the ICJ that an attack on a single military platform or installation might qualify as an armed attack; see ICJ Oil Platforms Judgment, paras. 57, 61.

24 Consider, in this regard, International Law Commission, Responsibility of States for Internationally Wrongful Acts, Annex to UNGA Resolution 56/83, 12 December 2001, Article 15 (Breach consisting of a composite act).

25 Note Tallinn Manual 2.0, Commentary accompanying Rule 71, para. 11. 
does not involve physical destruction but renders the $\mathrm{NC}_{3}$ architecture, or important elements of it, inoperable would qualify as an armed attack. ${ }^{26}$

7 The question of intent may, at first glance, appear to cause difficulty. Often, the victim State will be unaware of any particular intention that the person undertaking the attack, or the State on behalf of which he or she was acting, may have had. Victim States will generally and properly assume that the violent consequences of a violent act like the detonation of a nuclear device were intended, and will proceed on that basis. If it is apparent that the nuclear event was not intended, the question of whether it nevertheless constitutes an armed attack is moot, because the use of force in self-defence is unlikely to meet the necessity requirement (see Rule 12 below). ${ }^{27}$

8 If the gravity of the use of force meets the armed attack threshold and the relevant operation was actually undertaken by persons who are organs of a State, the attack is attributable to that State and therefore qualifies as an armed attack by that State. The actions of a non-State actor, such as a private individual, a contractor's employee or members of an armed group, may also be attributed to a State and may thus become the acts of that State if the relevant persons were sent by or on behalf of the State to undertake such acts. ${ }^{28}$ So, imagine that State A employs a private company to maintain computer systems in its defence ministry. If the State instructs a gifted hacker employed by that company to hack into State B's missile control computers, causing a missile that State B has test-fired to go off course and attack a civilian shopping centre with mass casualties, the attack would be attributable to State A and would have sufficiently grave consequences to constitute an armed attack. ${ }^{29}$ If a nuclear attack causes effects in more than one State, the gravity of the effects in each State must be considered in order to determine whether an armed attack has occurred against that State.

9 International law is not yet settled on the question whether an attack that is undertaken by an armed group without any participation by a State can constitute an armed attack for the purposes of Article 51 and of the customary law right to use force in self-defence. Traditionalists take the view that the notion of armed attack applies only in the case of a State-on-State activity, with lawful responses to violent actions by non-State actors, even those with a cross-border element, being limited to law enforcement. A more progressive

Consider Tallinn Manual 2.0, Commentary accompanying Rule 71, para. 12.

27 Note ICJ Oil Platforms Judgment, para. 64 .

28 ICJ Nicaragua Judgment, para. 195.

29 Tallinn Manual 2.0, Commentary accompanying Rule 71, para. 17. 
interpretation would point to resolutions of the UN Security Council ${ }^{3 \circ}$ and would note that Article 51 does not require the armed attack to be undertaken by a State. The 'if an armed attack occurs' language of Article 51, reflected in the present Rule, leaves open - perhaps deliberately - the question of the identity and status of the author of the armed attack. If, the progressives would say, the authors of Article 51 had wanted to narrow armed attacks down to actions of States, they could have done so explicitly in the same way as they did in Article 2(4). Traditionalists would complain that the progressive interpretation increases the scope for violent responses and thus is counter to the first, and arguably key, purpose of the United Nations - namely, to maintain international peace and security.

10 The present authors suggest that it would be illogical for the Security Council to characterise, as it has, terrorist acts by non-State actors as being capable of amounting to a threat to international peace ${ }^{31}$ while at the same time denying victim States the right to defend themselves against such threats. Moreover, State practice seems to suggest that States consider themselves entitled to resort to extra-territorial self-defence against non-State actors that have committed armed attacks against them or their allies. In this context, it suffices to refer to the allied military activities against the so-called Islamic State in Syria in response to that group's armed attacks against Iraq. Finally, the reference in Article 51 of the UN Charter to the 'inherent' right of selfdefence may be understood as an endorsement of the understanding of States before the adoption of the UN Charter. It may be recalled that the famous Caroline formula of 1842 was adopted with regard to British military operations against Canadian rebels who had taken refuge in the territory of the United States.

11 However, the sovereignty of the State from which the armed group operated must be properly respected. That State must be given a suitable opportunity to deal with the matter by taking steps to prevent any repetition. There is considerable controversy over what action the victim State can lawfully take if the State from which the armed group operated is either unable or unwilling to take effective preventive measures. Some governments and commentators argue that if the State 'hosting' the armed group is unable or unwilling to take effective preventive measures, the victim State has the right to use necessary and proportionate force in extra-territorial self-defence. They

30 Consider UNSC Resolution 1368 (2001), 12 September 2001; UNSC Resolution 1373 (2001), 28 September 2001; Statement by North Atlantic Council, 12 September 2001.

31 See UNSC Resolution 1368 (2001), 12 September 2001; UNSC Resolution 1373 (2001), 28 September 2001. 
rely either on the due diligence obligation or on the lack of effective sovereignty of the 'hosting' State. Other governments and commentators insist that justifying self-defence action in such circumstances on the basis of unable/ unwilling arguments unacceptably loosens the jus ad bellum constraints on the use of force. Accordingly, if an armed group located in State A were to use a nuclear device like a dirty bomb to create an explosion causing extensive destruction and damage and substantial numbers of casualties in State B, the effects would likely be sufficiently grave to meet the criteria for determining an armed attack. The important issue would then be the fact that it was an armed group based on the territory of State A that undertook the attack without the involvement of State A. The authorities of State A must be given a suitable opportunity to take required action to ensure that there is no repetition. If they are either unable or unwilling to do so, the controversy then arises. Some States, such as the United States, consider they have the legal right to use necessary and proportionate force in self-defence. Other States would dispute the legal right of State B to use force on the territory of State A in such circumstances. ${ }^{32}$

11 Further legal controversy attaches to the degree of organisation that is required for an armed group's violent activity to be characterisable as an armed attack. In the opinion of the present authors, the issue rather solves itself in the context of nuclear operations. For any kind of successful nuclear attack to be feasible, a very high level of group organisation is likely to be essential. Likewise, the capacity to mount an attack on a State's nuclear weapon facility will depend on operational co-ordination that, again, presupposes a very high level of organisation within the attacking group. In the less likely event that the attack is masterminded and executed by an individual acting alone, the authors believe that, in practice, a law enforcement response will be preferred in most circumstances.

12 The question that then arises is which violent acts outside the territory of a State nevertheless amount to an armed attack against that State. Attacks that target government employees and personnel and non-commercial facilities while they are located outside the territory of their State are capable of being armed attacks. Where other operations are concerned, the Tallinn Manual identifies relevant considerations as including: 'the extent of damage caused by the operation; whether the property involved is governmental or private in character; the status of the individuals who have been targeted; and whether the operations were politically motivated'. ${ }^{33}$

32 See also paras. 13 and 14 below.

33 Tallinn Manual 2.0, Commentary accompanying Rule 71, para. 22. 
13 The exercise of the right to use force in self-defence is subject to considerations of necessity and proportionality, as reflected in Rule 12; it can include action in the territory of the State from which the attack originated, in international waters and airspace and in outer space; and it can be undertaken by kinetic or cyber means. A self-defence operation involving activity in a State to which the armed attack cannot be attributed can be undertaken if that State consents. If the State in which the defensive action is to take place does not consent, it has been suggested that self-defence action is nevertheless lawful if the principle of necessity is complied with; if the action to be taken is the only effective means of defence against the armed attack; and, subject to the points made in paragraph 10 above, if the territorial State is unable or unwilling to take effective action to repress the activity constituting the armed attack. ${ }^{34}$

14 Even if the progressive view is accepted, the victim State is usually obliged to take specified steps before taking action. These required steps are driven by the continuing obligation to respect the sovereignty of the territorial State so far as possible. The victim State must therefore instruct the territorial State to stop the acts constituting the armed attack and must give it time in which to do so. By issuing such an instruction and by giving time for compliance, it reduces the risk of erroneous action in self-defence. However, circumstances may arise in which it is unrealistic to expect the victim State to delay acting after issuing such a demand. Consider a situation in which State A has reliable information that an armed group within State B is about to fire a rocket containing a dirty bomb at one of State A's major cities. Intercepted messages show that the weapon will be fired within a very short time, with devastating consequences if the bomb were to hit the intended target. In such a situation, the victim State can act in self-defence without having to issue a prior demand.

15 Article 51 of the UN Charter provides that the victim State of an armed attack enjoys the right of self-defence set forth in that Article until such time as the Security Council has taken necessary measures. This may not be reflective of customary international law, because, so far, the UNSC has never passed a binding resolution terminating the exercise of the right of individual or collective self-defence. In this context, it is also worthy of note that the reporting obligation set forth in the second sentence of Article 51 of the UN Charter is also not customary in nature. ${ }^{35}$

34 Tallinn Manual 2.0, Commentary accompanying Rule 71, para. 25.

35 ICJ Nicaragua Judgment, para. 235. 


\section{Necessity and Proportionality}

\section{Rule 12}

Force used by way of self-defence must be limited to what is necessary and proportionate.

1 The requirement that a State acting in self-defence may only use necessary and proportionate force is a rule of customary law. ${ }^{36}$

2 The first part of the Rule requires that the force that is used in self-defence be what is required 'to successfully repel an imminent armed attack or defeat one that is under way'. ${ }^{37}$ Other, non-forceful measures may also be taken at the same time, but the necessity element in the Rule is satisfied if non-forceful measures alone will not suffice to deal with the situation. In other words, if it appears unlikely that non-forceful measures will be enough to stop an armed attack and prevent further armed attacks, the use of force in self-defence will be lawful. The judgment as to whether forceful action in self-defence is necessary is a subjective assessment by the victim State based on information that is reasonably available to it. This excludes an ex post facto evaluation. Of course, the victim State must act reasonably when deciding whether forceful action is needed. The decision will regularly be reasonable if the situation fulfils the criteria of the Caroline formula, according to which the exercise of self-defence by a resort to armed force is necessary if the situation is "instant, overwhelming, leaving no choice of means, and no time for deliberation'.

3 Consider the example given in paragraph 14 of the Commentary accompanying Rule 11. If, as is likely to be the case, State A has no non-forceful way of preventing the firing of the rocket by the armed group in State B, the use of force by State A to stop the armed attack will meet the requirement of necessity. State A can make that judgment only on the basis of the information at its disposal. If it reasonably concludes that forceful action is needed and that no satisfactory non-forceful alternative is available, the necessity requirement is satisfied.

4 If the use of force is necessary in self-defence, the extent, duration and degree of the force actually used must not exceed what is needed to stop the armed attack or prevent the imminent armed attack. The amount of force that is required to achieve this will depend on the circumstances, and the degree of

$3^{6}$ ICJ Nicaragua Judgment, 176, 194; ICJ Nuclear Opinion, para. 41; ICJ Oil Platforms Judgment, paras. $43,73-4,76$. It should be borne in mind that this Rule is a rule of jus ad bellum. The principle of military necessity and the rule of proportionality that apply to military operations and to attacks during an armed conflict are separate notions and form part of a separate body of law, jus in bello.

37 Tallinn Manual 2.0, Commentary accompanying Rule 72, para. 2. 
force that is being applied in the actual or imminent armed attack will not dictate the degree of force that can lawfully be employed in self-defence. Equally, the kind of force that is used in self-defence may well be different to that being, or to be, employed in the armed attack.

5 It will be for the victim State to decide what kind and degree of forceful action in self-defence is needed. This will necessarily be a subjective assessment and must be based on the information reasonably available to that State. If information that was not available to the victim State at the time when it made its decision would have shown that the use of force in selfdefence was no longer necessary or that the degree of force that the victim State decided to use was no longer needed for that purpose, this will not render the decision to use force, or that much force, unlawful.

\section{Imminence and Immediacy}

\section{Rule 13}

A State may use force in self-defence if an armed attack occurs or is imminent. The forceful action must comply with the requirement of immediacy.

1 The right to use force in self-defence if 'an armed attack occurs' is directly referred to in the language of Article 51. An armed attack can be regarded for these purposes as occurring if the effects are already being experienced. In the case of a nuclear strike, the effects are being experienced when an explosion is occurring and/or when blast, fragmentation, heat, radiation or any combination thereof are causing injury and/or damage. A nuclear-armed attack is also occurring, for example, at the time when the munition carrying the nuclear device has been launched, fired or dropped towards the target.

2 The question that then arises in connection with nuclear operations is whether a State is required to wait until a weapon that is likely to have devastating effects on the target State has either exploded or has been fired before it is permitted to take any forceful action in self-defence. Article 51 of the UN Charter, by limiting itself to 'if an armed attack occurs', carefully avoids the issue. It must, however, be remembered that the right to use force in self-defence is inherent and that, independently of Article 51, the right is a rule of customary international law. Curiously, support for a right to use force in anticipatory self-defence against an imminent armed attack is, inter alia, to be found in the notion of necessity discussed in the Commentary accompanying Rule 12. If, once an armed attack is imminent, waiting until it commences would frustrate the ability to take effective action to prevent the infliction of a devastating blow, an interpretation of the self-defence right that permits 
forceful action only once the attack is under way would be inconsistent with an inherent right of States to use force to defend themselves. The present authors consider, therefore, that States have the inherent right to use necessary and proportionate force in self-defence, not only if an armed attack is under way but also if an armed attack is imminent. Further support for the right to use force where the armed attack is imminent is to be found in the well-known correspondence between Lord Ashburton and Daniel Webster arising from the Caroline incident.

3 There is a line of thought that considers that forceful action in selfdefence is lawful only if the armed attack has actually been initiated. ${ }^{3}$ In the nuclear context this would seem to imply that, for example, only when the missile carrying a nuclear warhead has been launched does the prospective victim State have the right to act in self-defence. With the development of technologies such as hypersonic missiles, States are likely to be given very little practical time in which to respond, and basic notions of national security are, it is thought, likely to drive most States into rejecting such a restrictive interpretation.

4 Academic discussion has debated the precise extent of permissible anticipatory self-defence. It has, for example, been suggested that the armed attack must be about to be launched for action in self-defence to be justified. The essential context for this discussion is the core purpose of the United Nations: maintenance of international peace and security. An excessively liberal interpretation of when force may be used in self-defence puts that very peace and security at risk if a greater set of circumstances is seen as justification for violent anticipatory action, while a more restrictive interpretation is going to be seen by many States as prejudicial to their individual security. A compromise interpretation that has been proposed would permit a State to take forceful action in self-defence if 'the attacker is clearly committed to launching an armed attack and the victim State will lose its opportunity to effectively defend itself unless it acts' ${ }^{39}$ This interpretation places less emphasis on the time dimension, in that the 'last window of opportunity' for a State to take effective action may be just as an attack is about to be launched, but may also be a considerable time before the commencement of the actual attack. It is thought that States will identify with this interpretation because it takes into account the variable circumstances in which self-defence decision-making

$3^{8}$ Consider Tallinn Manual 2.0, Commentary accompanying Rule 73, para. 3, citing I. Brownlie, International Law and the Use of Force by States (Oxford University Press, 1963) $275-8$.

39 Tallinn Manual 2.0, Commentary accompanying Rule 73, para. 4. 
must take place. It also recognises what the notion of self-defence is truly about - namely, the right of the victim or prospective victim to take necessary action to defend itself against grave attack. Requiring a State to wait until it is too late is actually depriving the State of that right and is therefore inconsistent with the inherent right of all States. Self-evidently, the longer the time interval before the armed attack is expected to occur, the more likely it is that the present time is not in fact the last window of opportunity. In this regard, the word 'last' deserves emphasis. The mere fact that 'a' window of opportunity to take effective action has arisen is not sufficient to render violent anticipatory action lawful. It must be the last opportunity in the subjective, but reasonable, opinion of the victim State.

5 Consider, for example, a situation in which the political leadership of State A has been threatening State B with nuclear attack. State B knows that the nuclear warheads are in long-term storage at a facility located deep underground. State B detects that the nuclear warheads are being moved from the long-term storage facility to another underground storage bunker located on a military base from which nuclear-capable missiles are launched. State A has announced that it will target State B with a nuclear missile attack at a time of its own choosing. If State B, acting in good faith, believes that the last opportunity it will have to take effective action in self-defence is by attacking the missiles while they are in transit from long-term storage to the military base, it would be justified, according to the last window of opportunity approach, in using necessary and proportionate force in self-defence at that moment. State B cannot sensibly be required to know exactly when State A plans to launch its nuclear attack, but its action in self-defence will be lawful only if it can be shown that State A does indeed have a firm intention to launch such an attack, or at least that it is reasonable for State B to conclude from the reasonably available information that State A so intends.

6 An important distinction must be drawn between activity that really forms part of the armed attack and activity that is not necessarily contributing to the conduct of the attack as such. So, the whole of the sequence of actions that must, in the ordinary course of events, be completed as part of the process leading to the firing of the missile forms part of the actual conduct of the armed attack. Once that sequence is commenced, the armed attack is under way. The loading of target data into the missile guidance system may be a preparatory act, but if it is done as part of the pre-firing procedure that action arguably also becomes part of the actual conduct of the armed attack. Other activities whose purpose is to maintain the readiness of the missile for future use constitute preparation, not the conduct of an attack. However, actions that represent the last window of opportunity for the target State to take effective 
action in anticipatory self- defence may take place during the preparatory phase. Ultimately the lawfulness of the victim state's action in self-defence will depend on whether it was reasonable for it to use force to protect itself in the particular circumstances, whether it was necessary for force to be used and whether the amount of force used was that required to deal effectively with the situation.

7 In the example discussed in paragraph 5 but varying the facts somewhat, imagine that State A has developed a nuclear weapon capability and has published doctrine in which it asserts its willingness to use such weapons in circumstances where it has been the subject of a prior devastating armed attack. Tensions arise between State A and State B. State B would not be entitled to use force in self-defence on the mere ground that State A possesses nuclear weapons. The doctrinal statements by State A would also not justify the use of force by State B in self-defence, because they do not reveal any intent on the part of State A to use force, nuclear or otherwise, specifically against State B. Aggressive statements directed by State A against State B, but without evidence that State A is actually preparing to undertake an armed attack, also will not justify the use of force by State B. If, however, State A's statements and/or the actions it is seen to take manifest a clear intent to undertake against State B an attack that will rise to the level of an armed attack, State B would be legally permitted, in self-defence, to use force that is necessary and proportionate (see Rule 12) when the last realistic window of opportunity effectively to do so presents itself.

8 If the use of force in self-defence cannot be justified, but an internationally wrongful act has been committed by State A, State B may consider the use of countermeasures (Rule 7). It may also consider referring the matter to the UN Security Council (see Rule 16).

9 The requirement of immediacy, reflected in the second sentence of the Rule, addresses the interval that can properly elapse between the armed attack and the taking of action in self-defence. Depending on the precise nature and effect of the armed attack, a victim State may require a certain period of time to be in a position to take appropriate action in self-defence. The identity of an attacker that has used a nuclear weapon will usually be clear. However, time may be needed in order to decide which target(s) it would be proper to attack in self-defence, to make the necessary military deployment arrangements to be in a position to do so and, perhaps, to achieve the political consensus in the victim State in favour of defensive military action.

10 If an excessive period is allowed to elapse after the armed attack has taken place, the lawfulness of the self-defence action may be doubtful. Consider a situation in which a nuclear-capable State, State A, uses a conventional weapon to undertake an armed attack against a neighbouring State, 
State B. State B is undecided as to whether it should use force in self-defence. A consensus cannot be achieved in its legislature and discussions take place between the governing party and the opposition. Eventually, after a number of weeks have elapsed, a consensus is achieved in favour of a limited strike in response. Appropriate instructions are given to the armed forces and the strike in response is undertaken a week after the political approval was given. Where the lawfulness of State B's strike in response is concerned, much will depend on what has been going on during that period of delay. If there have been no further uses of force by State A and if there is no indication of an intention on the part of State A to undertake further attacks, the immediacy requirement will likely not be satisfied, such that the use of force in response by State B will have been unlawful. If, however, during the period of delay there have been continuing threats or ongoing activities by State A, in either case showing that a further attack can be anticipated, the use of force in response would likely be regarded as lawful. Inevitably, however, much will depend on the particular circumstances and on the reasonableness of State B's conclusion that further attacks are likely to follow.

\section{Collective Self-Defence}

\section{Rule 14}

If a request for assistance is made by a State that is the victim of an armed attack, another State may exercise the inherent right of collective self-defence; forceful action taken in collective self-defence must be in accordance with any limitations imposed by the victim State.

1 This Rule is based on the wording of Article 51 of the UN Charter and reflects customary law. A State that has suffered an armed attack may request selfdefence assistance from another State. Equally, if several States have been victims of an armed attack, they may act collectively in self-defence. However, a request for assistance must have been made by the State that is the victim of an armed attack to the assisting State before the latter is permitted to come to its aid by using force. ${ }^{4^{\circ}}$ Both or all States that are involved in a collective selfdefence operation must satisfy themselves individually that the right to use force in collective self-defence has arisen.

2 Not only must the assisting State(s) use force in self-defence only if requested by the victim State to do so, but the force that it uses must accord with any limitations imposed by the victim State. The victim State may, for

$4^{\circ}$ ICJ Nicaragua Judgment, para. 199. 
example, stipulate that certain kinds of weapon are not to be used, that certain kinds of target are not to be made the object of attack or that targets located beyond certain longitudes or latitudes are not to be made the object of attack. Such limitations must apply in addition to, and without prejudice to, the rules of targeting set forth in the law of armed conflict.

3 The collective self-defence arrangement may be reflected in a formal agreement that provides for future contingencies. The obvious example of such an agreement is Article 5 of the North Atlantic Treaty, which stipulates, in relation to State parties, that 'an armed attack against one or more of them in Europe or North America shall be considered an attack against them all and consequently they agree that, if such an armed attack occurs, each of them, in exercise of the right of individual or collective self-defence recognised by Article 51 of the Charter of the United Nations, will assist the Party or Parties so attacked'. ${ }^{41}$ Accordingly, Article 5 gives standing consent to the use of force by any member State of NATO in collective self-defence of another member State that is the victim of an armed attack. Such standing consent may equally be reflected in an agreement between two States or in some other form of inter-State arrangement. Finally, a request may form part of an ad hoc agreement. What matters is not so much the formalities associated with the document as the fact of an agreement between the victim and assisting State(s). The action taken by the assisting State(s) must then be in accordance with the limitations, if any, prescribed in the agreement.

4 Rules 12 and 13 on necessity, proportionality, imminence and immediacy apply to collective self-defence, just as they apply to action taken in selfdefence by the victim State.

\section{Reporting Self-Defence Action to the UN Security Council}

\section{Rule 15}

Measures taken by a State in the exercise of the right of self-defence provided for in Article 51 of the UN Charter must be immediately reported to the UN Security Council and do not affect the authority and responsibility of the Security Council under the UN Charter to take at any time such action as it deems necessary in order to maintain or restore international peace and security.

1 This Rule closely follows the language of the second part of Article 51 of the UN Charter. Although the Rule is not reflective of customary law, ${ }^{42}$ the

41 North Atlantic Treaty, 4 April 1949, 34 UNTS 243, Article 5.

42 ICJ Nicaragua Judgment, para. 235. 
obligation is binding on all States as a matter of treaty law, as all States are members of the United Nations.

2 The reporting obligation arises once self-defence measures are taken. There is no obligation to inform the Security Council in advance of the taking of self-defence action, but once self-defence action has been taken the Security Council must be informed straight away.

3 If a State were to employ forceful action in self-defence but then failed to report in accordance with the Rule, that would constitute a breach of Article 51 but would not render the action taken in self-defence unlawful, nor would the failure to submit the report deprive the victim State of the right to continue, in self-defence, with necessary and proportionate action that satisfies the imminence and immediacy requirements of Rules 12 and 13.

4 The facts that a State is acting in lawful self-defence and that a report under the present Rule has been sent to the Security Council does not affect the responsibility and authority of the Security Council to take the steps that it considers to be necessary in accordance with Chapter VII of the UN Charter (on which, see Rules 16 and 17).

\section{UN Security Council Action}

\section{Rule 16 \\ If the United Nations Security Council determines that action employing or in relation to nuclear weapons constitutes a threat to the peace, a breach of the peace or an act of aggression, it may decide what measures not involving the use of armed force are to be employed.}

1 Article 39 of the UN Charter gives the Security Council the responsibility to decide if there has been a threat to the peace, a breach of the peace or an act of aggression. ${ }^{43}$ Once the Security Council has decided that one of the three situations listed in Article 39 has arisen, Article 41 of the UN Charter provides that it "may decide what measures not involving the use of armed force are to be employed to give effect to its decisions, and it may call upon the Members of the United Nations to apply such measures. These may include complete or partial interruption of economic relations and of rail, sea, air, postal, telegraphic, radio, and other means of communication, and the severance of diplomatic relations.'

43 The text of Article 39 is: "The Security Council shall determine the existence of any threat to the peace, breach of the peace, or act of aggression and shall make recommendations, or decide what measures shall be taken in accordance with Articles 41 and 42 , to maintain or restore international peace and security.' 
2 Of considerable relevance to the topic of this book, the Security Council has identified the proliferation of weapons of mass destruction as a threat to the peace. ${ }^{44}$ Equally, it may characterise a particular event or situation as a threat to the peace, a breach of the peace or an act of aggression. Consider a situation in which one State threatens another with nuclear attack or in which a State, confronted with a nuclear-armed State, threatens to take forceful action against its competitor's nuclear weapons facilities. Article 39 permits the Security Council, after considering the circumstances, to decide whether the situation comes within the Article and, if it does, to assess whether non-forceful action under Article 41 would be a suitable way of dealing with the matter. Moreover, the Security Council has the power to decide that certain generic kinds of nuclear weapon-related activity also come within Article 39. However, depending on the exact terms of such a proposed measure, it is perhaps likely that at least one of the five permanent members of the Security Council would veto such a decision.

3 The list of non-forceful measures given in Article 41 is non-exhaustive. Other categories of non-forceful action might be decided upon by the Security Council. The chosen measures will be those that, in the opinion of the Security Council, are most suitable for dealing effectively with the circumstances that gave rise to the Article 39 determination.

4 The decisions that the Security Council takes under Chapter VII must be implemented by all States, ${ }^{45}$ but individual States have a discretion over how to go about implementing the Security Council's decision. Much will inevitably depend on the circumstances. Some measures may require the passing of legislation or the issuing of internal, national instructions or regulations. Other steps may necessitate the taking of practical action to stop particular activities referred to in the Security Council decision.

\section{Forceful Action by the UN Security Council}

\section{Rule 17}

If the Security Council has determined the existence of a threat to the peace, a breach of the peace or an act of aggression and if it considers that measures not involving the use of armed force would be inadequate or have proved to be inadequate, it may take such forceful action as is necessary to maintain or restore international peace and security.

1 This Rule is based on Article 42 of the UN Charter, which provides: 'Should the Security Council consider that measures provided for in Article 41 would

44 UNSC Resolution 1540 (2004), 28 April 2004.

45 UN Charter, Article 25. 
be inadequate or have proved to be inadequate, it may take such action by air, sea, or land forces as may be necessary to maintain or restore international peace and security. Such action may include demonstrations, blockade, and other operations by air, sea, or land forces of Members of the United Nations.'

2 The required sequence of events is that, first, the Security Council must determine the existence of a threat to the peace, a breach of the peace or an act of aggression. If it does this, it must then decide whether non-forceful measures would be inadequate, or have proved to be inadequate, to deal with the relevant situation. This does not oblige the Security Council to necessarily try non-forceful measures. It is entitled to consider the situation it is dealing with and to conclude that non-forceful measures will not be an effective way of maintaining or restoring international peace and security. If it reaches that conclusion, the Security Council may authorise the use of force.

3 Consider a situation in which a State has declared that it has placed its nuclear weapon forces on a heightened level of readiness and has issued threatening, bellicose statements directed at a neighbouring State with which it has a dispute over the sovereignty of certain islands. The Security Council is likely to conclude that, when considered in the context of the bellicose statements, placing the nuclear weapon forces on heightened readiness constitutes a threat to the peace. Which measures are most likely to have the practical effect of maintaining international peace when a nuclear power is speaking and/or acting aggressively will be a matter for very careful deliberation. It is entirely possible that non-forceful measures will be preferred, for fear that any use of force will risk igniting a most dangerous set of circumstances. Equally, and depending on the facts, force may be the only option, although it is likely that the scope of the force that is being authorised will be carefully circumscribed.

4 When issuing a resolution under Article 42 of the Charter, the Security Council often authorises the taking of 'all necessary measures' to achieve the purposes stated in the resolution. ${ }^{46}$ The language of the resolution will specify the purpose that 'all necessary measures' must be designed to achieve, but the term is generally understood as permitting the use of armed force in order to bring about the desired outcome. In the opinion of the present authors, a Security Council resolution containing this phrase will not be regarded by States as a sufficient authority for the use of a nuclear weapon by the armed forces implementing the resolution. ${ }^{47}$ It is, however, imaginable that an armed

46 UNSC Resolution 1973 (2011), 17 March 2011.

47 This is on the assumption that the UNSC resolution does not contain a specific authorisation to use a nuclear weapon. Inclusion by the Security Council of a specific authorisation of that kind would seem to be most unlikely. 
conflict that commences when force is used to implement such a resolution might subsequently give rise to a situation in which the use of a nuclear weapon is considered. In such a circumstance, the lawfulness of a threat or use of a nuclear weapon will be determined taking into account the factors discussed in Section J (discussion of ICJ Nuclear Opinion) and Section E (jus in bello).

5 Article 103 of the UN Charter provides: 'In the event of a conflict between the obligations of the Members of the United Nations under the present Charter and their obligations under any other international agreement, their obligations under the present Charter shall prevail.' This Article makes it clear that the Security Council is not required to take States' obligations under other legal arrangements into account when deciding on action under Article 42. However, States may disregard their obligations under other international agreements only if they actually conflict with their UN Charter obligations, and they may do so only for as long as such a conflict persists. The ability of the Security Council to ignore other international obligations of States is limited, however. For example, it may not deviate from jus cogens rules. ${ }^{4}$

\section{Regional Organisations}

\section{Rule 18}

If the United Nations Security Council mandates or authorises such action, international organisations, arrangements or agencies of a regional nature may conduct enforcement action in respect of nuclear weapons.

1 Article 53(1) of the UN Charter specifies that " $t$ t]he Security Council shall, where appropriate, utilize ... regional arrangements or agencies for enforcement action under its authority. But no enforcement action shall be taken under regional arrangements or by regional agencies without the authorization of the Security Council ... ' The language of the Charter seems to encourage the Security Council to use regional arrangements or agencies for enforcement purposes, but suggests that prior authorisation of the Security Council is required before any enforcement action, whether under Rule 16 (Article 41) or Rule 17 (Article 42), can be taken by a regional arrangement or agency.

2 Little turns on the exact meaning of 'regional arrangements or agencies'. Under Article 48 of the Charter, 'action required to carry out the decisions of the Security Council for the maintenance of international peace and security

$4^{8}$ Tallinn Manual 2.o, Commentary accompanying Rule 76, para. 9. 
shall be taken by all the Members of the United Nations or by some of them, as the Security Council may determine. ${ }^{19}$ Article 48 continues: 'Such decisions shall be carried out by the Members of the United Nations directly and through their action in the appropriate international agencies of which they are members. ${ }^{50}$ It is therefore clear that the Security Council may authorise enforcement action by any group of States, whether previously formed into a formal arrangement or simply brought together by the circumstances that give rise to the enforcement action. In particular, and notwithstanding the reference to 'regional arrangements or agencies' in Chapter VIII of the Charter, there is no requirement for such a group to be linked with a geographical region.

3 'Enforcement action' in the present Rule means action under Article 41 or Article 42 of the UN Charter (see Rules 16 and 17 respectively). The word 'mandates' refers to a situation in which the Security Council has specifically mandated a regional arrangement or agency to undertake enforcement action. The word 'authorises' refers to a situation in which a regional arrangement or agency, or indeed individual States, perhaps acting as a coalition, take action under a more general authorisation issued by the Security Council.

50 Ibid., Article 48(2). 